\title{
PERBANDINGAN KEMAMPUAN DAUN CENGKEH DAN DAUN PEPAYA TERHADAP MORTALITAS LARVA AEDES AEGEPTY DI KOTA TERNATE
}

\author{
Sakriani $^{1}$, Nur Ilma Hidayat ${ }^{1}$, Nuke Dianita ${ }^{1}$ \\ ${ }^{1}$ Jurusan Kesehatan Lingkunan Poltekkes Kemenkes Ternate
}

\begin{abstract}
ABSTRAK
Latar Belakang. Demam Berdarah Dengue (DBD) merupakan salah satu penyakit menular yang masih menjadi masalah yang dihadapi Indonesia. Penangan DBD dilakukan dengan mengendalikan vektornya. Salah satu usaha pengendalian vektor adalah pada usia jentik (larva), baik dengan cara biologi yaitu menggunakan musuh-musuh alami maupun dengan cara kimiawi yang menggunakan zat kimia berefek larvasida. Tujuan. Tujuan penelitin ini adalah untuk mengetahui perbandingan kemampuan perasan daun cengkeh dan daun pepaya pada konsentrasi 10\%, 15\%, dan 20\% terhadap mortalitas Aedes aegypti. Metode Penelitian. Penelitian ini adalah penelitian eksperimental dengan rancangan Post Test Only Controlled Design. Sampel pada penelitian ini adalah larva Aedes aegypti instar III. Teknik pengambilan sampel pada penelitian ini adalah Simple Random Sampling. Hasil. Hasil penelitian menunjukkan bahwa pada konsentrasi $10 \%$, rata-rata larva yang mati pada perasan daun cengkeh adalah 4 sedangkan pada perasan daun pepaya hanya 1 . Pada konsentrasi $15 \%$, ratarata larva yang mati pada perasan daun cengkeh adalah 10 sedangkan pada perasan daun pepaya hanya 1. Pada konsentrasi $20 \%$, rata-rata larva yang mati pada perasan daun cengkeh adalah 10 sedangkan pada perasan daun pepaya hanya 1. Kesimpulan. Rata-rata larva yang mati pada perasan daun cengkeh di tiap konsentrasi lebih banyak dibandingkan dengan perasan daun pepaya. Pada kontrol, tidak ada larva yang mati sama sekali.
\end{abstract}

Kata kunci: daun cengkeh, daun pepaya, larvasida, Aedes aegypti

\section{PENDAHULUAN}

Demam Berdarah Dengue (DBD) atau Dengue Hemorrhagic Fever (DHF) masih merupakan salah satu masalah kesehatan di Indonesia. Pada Tahun 2014 terdapat 100.347 kasus DBD dari 252.124.458penduduk dengan Angka Insiden (Incidence Rate) sebesar 39,80 dan CFR sebesar 0,9. Angka Kefatalan Kasus atau Case Fatality Rate (CFR) kasus DBD di Maluku Utara lebih besar jika dibandingkan dengan CFR DBD di Indonesia, yakni sebesar 1,35. Jumlah kematian ada 2 dari 148 Kasus DBD di Maluku Utara (Profil Kesehatan Indonesia, 2014). Terdapat 32 kasus DBD di Kota Ternate pada tahun 2012. Tahun berikutnya terjadi peningkatan kasus yakni 63 penderita DBD dan terdapat 2 penderita di antaranya yang meninggal $(\mathrm{CFR}=3 \%)$. Pada tahun 2014 terjadi penurunan kasus menjadi 51 penderita, tetapi masih teradapat kasus kematian yakni 1 penderita yang meninggal $(\mathrm{CFR}=1 \%)$ (La Haeda, 2015).

Beberapa penelitian yang telah dilakukan menunjukkan bahwa beberapa tanaman dapat dijadikan sebagai pengganggu dan bahkan dapat menurunkan jumlah Aedes aegypti, di antaranya adalah daun cengkeh dan daun pepaya (Sandjaya, dkk., 2014; Kurniawan, B, dkk., 2014, Sadhana, 2015) . Beberapa penelitian telah menunjukkan bahwa ekstrak daun cengkeh dapat menurunkan jumlah larva Aedes aegypti. Penelitian yang dilakukan oleh Haditomo (2010) menunjukkan bahwa Ekstrak daun cengkeh (Syzygium aroticum L.) memiliki efek larvasida terhadap Aedes aegypti L. dengan LC50 dan LC99 pada konsentrasi $0,040 \%$ atau 400 ppm pada konsentrasi $0,091 \%$ atau $910 \mathrm{ppm}$. 
Penelitian yang dilakukan oleh Taher (2015), dkk. juga menunjukkan hasil yang serupa, cengkeh varietas afo berpotensi sebagai larvasida alami penanggulangan vektor nyamuk DBD. Tingkat kematian larva Aedes aegypti sebesar $80 \%$ akibat infusa daun cengkeh varietas afo pada konsentrasi 20\% dengan lama aplikasi 15 jam (Taher, dkk, 2010).

Penelitian yang dilakukan oleh Ariesta, A. A., dkk. menunjukkan bahwa ada pengaruh larutan daun pepaya (Carica papaya) terhadap kematian larva nyamuk Aedes aegypti instar II" (Ariesta, A. A., dkk., 2014). Penelitian yang dilakukan oleh (Tyas, 2012) juga menunjukkan ada pengaruh biolarvasida ekstrak daun papaya (Carica papaya L) terhadap kematian larva Aedes aegypti. Penelitian yang dilakukan oleh Irwindiani, dkk. menunjukkan bahwa perasan daun pepaya dapat menyebabkan mortalitas larva Anopheles sp. Perasan daun pepaya dengan konsentrasi $20 \%$ menyebabkan kematian larva sebesar $100 \%$ (Irwindiani, dkk., 2015).

Uraian tersebut menunjukkan bahwa ekstrak daun pepaya dan ekstrak daun cengkeh efektif menyebabkan kematian larva Aedes aegypti dan perasan daun pepaya dengan konsentrasi $20 \%$ menyebabkan kematian larva Anopheles sp. Namum, belum dilakukan penelitian yang menguji perdandingan efektifitas perasan daun pepaya dan daun cengkeh dalam menyebabkan kematian larva Aedes aegypti. Hal ini menjadi latar belakang peneliti untuk melakukan penelitian tentang perbandingan efektivitas perasan daun cengkeh dan daun pepaya pada konsentrasi tertentu $(10 \%, 15 \%$, dan $20 \%)$ dalam menurunkan jumlah larva Aedes aegypti.

\section{METODE}

Penelitian ini adalah penelitian eksperimental dengan rancangan Post Test Only Controlled Design. Sampel pada penelitian ini adalah larva Aedes aegypti instar III. Jumlah larva yang digunakan pada sampel ini adalah sebanyak 380 ekor. Teknik pengambilan sampel pada penelitian ini adalah Simple Random Sampling.

Data sekunder mengenai kasus DBD, kepadatan jentik Aedes aegypti dikumpulkan melalui studi pustaka. Pengumpulan data mengenai efektivitas perasan daun cengkeh dan daun pepaya dalam menurunkan larva Aedes aegypti dilakukan dengan observasi langsung.

Analisis data dilakukan dengan menggunakan Uji Dependent t test (untuk data terdistribusi normal) atau Uji Mann Withney (untuk data tidak terdistribusi normal) untuk membandingkan antara setiap kelompok perlakuan dan perlakuan lainnya dan kelompok perlakukan dengan kelompok kontrol dan Uji Anova (untuk data terdistribusi normal) atau Uji Kruskal Wallis (untuk data tidak terdistribusi normal) untuk membandingkan semua kelompok yang diteliti.

\section{HASIL}

Tabel 5.1

Perbandingan Kemampuan Daun

Cengkeh dan Daun Pepaya Terhadap Mortalitas

Larva Aedes aegypti di Kota Ternate

\begin{tabular}{|c|c|c|c|c|c|c|c|}
\hline \multirow{2}{*}{ Waktu } & \multicolumn{2}{|c|}{$10 \%$} & \multicolumn{2}{|c|}{$15 \%$} & \multicolumn{2}{|c|}{$20 \%$} & $\mathbf{K}$ \\
\hline & $\mathbf{C}$ & $\mathbf{P}$ & $\mathbf{C}$ & $\mathbf{P}$ & $\mathbf{C}$ & $\mathbf{P}$ & K \\
\hline $13 / 11 / 201$ & & & & & & & \\
\hline $\begin{array}{c}6 \\
05: 00 \\
\end{array}$ & 2 & 0 & 5 & 0 & 6 & 0 & 0 \\
\hline $13 / 11 / 201$ & & & & & & & \\
\hline $\begin{array}{c}6 \\
11: 00 \\
\end{array}$ & 1 & 0 & 2 & 0 & 1 & 0 & 0 \\
\hline $13 / 11 / 201$ & & & & & & & \\
\hline $\begin{array}{c}6 \\
17: 00 \\
\end{array}$ & 2 & 1 & 3 & 0 & 2 & 0 & 0 \\
\hline $13 / 11 / 201$ & & & & & & & \\
\hline $\begin{array}{c}6 \\
23: 00\end{array}$ & 0 & 0 & 0 & 1 & 1 & 1 & 0 \\
\hline Jumlah & 5 & 1 & $\begin{array}{l}1 \\
0\end{array}$ & 1 & 0 & 1 & 0 \\
\hline
\end{tabular}

Keterangan:

$\mathrm{C}=$ Perasan daun cengkeh

$\mathrm{P}=$ Perasan daun pepaya

$\mathrm{K}=$ Kontrol 
Tabel 5.1 menunjukkan bahwa jumlah larva yang mati lebih banyak pada perasan daun cengkeh dibandingkan perasan daun pepaya pada semua konsentrasi. Pada kelompok perasan pepaya, hanya 1 larva yang mati pada tiap konsentrasi. Bahkan, pada kelompok kontrol, tidak ada larva yang mati.

Tabel 5.2

Perbandingan Kemampuan Daun

Cengkeh dan Daun Pepaya Terhadap

Mortalitas

Larva Aedes aegypti di Kota Ternate

\begin{tabular}{|c|c|c|c|c|c|c|c|}
\hline \multirow{2}{*}{ Waktu } & \multicolumn{2}{|c|}{$10 \%$} & \multicolumn{2}{|c|}{$15 \%$} & \multicolumn{2}{|c|}{$20 \%$} & \multirow{2}{*}{$\mathbf{K}$} \\
\hline & $\mathrm{C}$ & $\mathbf{P}$ & $\mathbf{C}$ & $\mathbf{P}$ & $\mathbf{C}$ & $\mathbf{P}$ & \\
\hline $14 / 11 / 20$ & & & & & & & \\
\hline $\begin{array}{c}16 \\
05: 00\end{array}$ & 1 & 0 & 9 & 0 & 6 & 0 & 0 \\
\hline $14 / 11 / 20$ & & & & & & & \\
\hline $\begin{array}{c}16 \\
11: 00\end{array}$ & 0 & 1 & 0 & 3 & 1 & 1 & 0 \\
\hline $14 / 11 / 20$ & & & & & & & \\
\hline $\begin{array}{c}16 \\
17: 00\end{array}$ & 1 & 0 & 0 & 0 & 2 & 0 & 0 \\
\hline $14 / 11 / 20$ & & & & & & & \\
\hline $\begin{array}{c}16 \\
23: 00\end{array}$ & 0 & 0 & 0 & 0 & 1 & 0 & 0 \\
\hline Jumlah & 2 & 1 & 9 & 3 & $\begin{array}{l}1 \\
0\end{array}$ & 1 & 0 \\
\hline
\end{tabular}

Keterangan:

$\mathrm{C}=$ Perasan daun cengkeh

$\mathrm{P}=$ Perasan daun pepaya

$\mathrm{K}=$ Kontrol

Pengulangan penelitian yang kedua kalinya menunjukkan hasil yang tidak jauh berbeda pada penelitian pertama. Jumlah larva yang mati lebih banyak pada perasan daun cengkeh di tiap konsentrasi. Pada 6 jam pertama, larva lebih banyak mati pada penelitian kedua dibandingkan dengan penelitia pertama. Pada penelitian kedua larva mati sebanyak 9 pada konsentrasi $15 \%$ dan 6 1pada konsentrasi $20 \%$.

Tabel 5.3

Perbandingan Kemampuan Daun

Cengkeh dan Daun Pepaya Terhadap Mortalitas

Larva Aedes aegypti di Kota Ternate

\begin{tabular}{|c|c|c|c|c|c|c|c|}
\hline \multirow{2}{*}{ Waktu } & \multicolumn{2}{|c|}{$10 \%$} & \multicolumn{2}{|c|}{$15 \%$} & \multicolumn{2}{|c|}{$20 \%$} & \multirow{2}{*}{$\mathbf{K}$} \\
\hline & C & $\mathbf{P}$ & C & $\mathbf{P}$ & C & $\mathbf{P}$ & \\
\hline $15 / 11 / 201$ & & & & & 1 & & \\
\hline $\begin{array}{c}6 \\
05: 00\end{array}$ & 1 & 0 & 2 & 0 & $\begin{array}{l}1 \\
0\end{array}$ & 0 & 0 \\
\hline $15 / 11 / 201$ & & & & & & & \\
\hline $\begin{array}{c}6 \\
11: 00 \\
\end{array}$ & 0 & 0 & 1 & 0 & 0 & 0 & 0 \\
\hline $15 / 11 / 201$ & & & & & & & \\
\hline $\begin{array}{c}6 \\
17: 00 \\
\end{array}$ & 2 & 1 & 3 & 0 & 0 & 0 & 0 \\
\hline $15 / 11 / 201$ & & & & & & & \\
\hline $\begin{array}{c}6 \\
23: 00 \\
\end{array}$ & 3 & 0 & 4 & 0 & 0 & 0 & 0 \\
\hline Jumlah & 6 & 1 & $\begin{array}{l}1 \\
0\end{array}$ & 0 & 0 & 0 & 0 \\
\hline
\end{tabular}

\section{Keterangan:}

$\mathrm{C}=$ Perasan daun cengkeh

$\mathrm{P}=$ Perasan daun pepaya

$\mathrm{K}=$ Kontrol

Tabel 5.3 menunjukkan bahwa hasil pengulangan penelitian ketiga tidak terlalu jauh berbeda dengan penelitian pertama dan kedua. Jumlah larva yang mati lebih banyak pada perasan daun cengkeh dibandingkan dengan perasan daun pepaya di setiap konsentrasi. bahkan, pada kelompok kontrol tidak ada larva yang mati.

Tabel 5.4

Perbandingan Kemampuan Daun

Cengkeh dan Daun Pepaya Terhadap Mortalitas

Larva Aedes aegypti di Kota Ternate

\begin{tabular}{|c|c|c|c|c|c|c|c|}
\hline \multirow[b]{2}{*}{$\begin{array}{l}\text { Konsentrasi } \\
\text { Ulangan }\end{array}$} & \multicolumn{2}{|c|}{$10 \%$} & \multicolumn{2}{|c|}{$15 \%$} & \multicolumn{2}{|c|}{$20 \%$} & \multirow[b]{2}{*}{$\mathbf{K}$} \\
\hline & C & $\mathbf{P}$ & C & $\mathbf{P}$ & $\mathbf{C}$ & $\mathbf{P}$ & \\
\hline $\mathrm{I}$ & 5 & 1 & $\begin{array}{l}1 \\
0\end{array}$ & 1 & 10 & 1 & 0 \\
\hline II & 2 & 1 & 9 & 3 & 10 & 1 & 0 \\
\hline III & 6 & 1 & $\begin{array}{l}1 \\
0\end{array}$ & 0 & 10 & 0 & 0 \\
\hline Jumlah & 13 & 3 & $\begin{array}{l}2 \\
9\end{array}$ & 4 & 30 & 2 & 0 \\
\hline Rata - rata & 4 & 1 & $\begin{array}{l}1 \\
0\end{array}$ & 1 & 10 & 1 & 0 \\
\hline
\end{tabular}

Keterangan:

$\mathrm{C}=$ Perasan daun cengkeh

$\mathrm{P}=$ Perasan daun pepaya

$\mathrm{K}=$ Kontrol 
Tabel 5.4 menunjukkan rata-rata jumlah larva yang mati untuk tiga kali pengulangan, baik pada perasan daun cengkeh, perasan daun pepaya, maupun kelompok kontrol. Rata-rata larva yang mati pada perasan daun cengkeh di tiap konsentrasi lebih banyak dibandingkan dengan perasan daun pepaya. Pada kontrol, tidak ada larva yang mati sama sekali.

\section{PEMBAHASAN}

Pada perasan daun cengkeh konsentrasi $15 \%$ dan $20 \%$, semua larva mati setelah 24 jam. Pada perasan $10 \%$ hanya sebagian larva yang mati, sebagian lainnya masih hidup hingga 24 jam. Semakin besar konsentrasi perasan daun cengkeh, semakin besar kemampuan dalam menyebabkan kematian larva. Daun cengkeh mengandung eugenol, saponin, flavonoid dan tanin. Eugenol merupakan senyawa aromatik, berbau dan dapat larut pada air (Haditomo, 2010; Nurdjannah, Nanan., 2013). Eugenol dapat mempengaruhi susunan saraf yang khas yang dipunyai serangga dan tidak terdapat pada hewan berdarah panas. Terganggunya saraf serangga tersebut, dapat menyebabkan kematian larva (Hastutiningrum, N.O, 2010). Saponin juga memiliki kontribusi dalam menyebabkan kematian larva. Saponin menyebabkan gangguan fisik dari larva. Saponin masuk melalui organ pernafasan dan menyebabkan kerusakan membran sel serta mengganggu proses metabolilsme pada larva (Haditomo, 2010). Flavonoid merupakan senyawa bersifat toksik yang terdapat pada daun cengkeh. Flavonoid juga memiliki sifat yang dapat menghambat proses mencerna makanan pada serangga. Selain flavonoid, tanin yang terdapat pada daun cengkeh juga dapat menghambat larva dalam mencerna makanan. Jentik yang terpapar dengan senyawa ini mengalami gangguan nutrisi dan penurunan laju pertumbuhan ${ }^{1}$. Beberapa penelitian lain juga menunjukkan efek larvasida daun cengkeh terhadap larva Aedes sp. Minyak atsiri daun cengkeh (Syzygium aromaticum
L.) memiliki efek terhadap mortalitas larva Aedes aegypti dengan $\mathrm{LC}_{50}$ pada konsentrasi 0,040\% (400 ppm) dan $\mathrm{LC}_{99}$ pada konsentrasi 0,091\% (910 ppm $)^{1}$. Hasil penelitian oleh Taher, dkk. juga menunjukkan bahwa pengggunaan ekstrak daun cengkeh memberikan pengaruh terhadap kematian larva nyamuk $A e$. Aegypti (Taher, dkk., 2015). Ekstrak daun cengkeh dengan konsentrasi 1.593 ppm dengan waktu pajanan $12-24$ jam efektif dalam menyebabkan kematian larva $A e$. aegypti (Kristijanto, A.I., dkk., 2011).

Daun pepaya juga mengandung beberapa senyawa yang dapat menyebabkan gangguan hingga terjadinya kematian larva. Namun, pada penelitian ini hanya sedikit larva yang mati setelah dilakukan percobaan selama 24 jam. Sebagian besar larva masih hidup setelah 24 jam dimasukkan ke dalam larutan yang berisi perasan daun pepaya. Pada tiap konsentrasi pada tiap pengulangan, hanya 1 larva yang mati hingga 24 jam setelah dimasukkan ke dalam wadah yang berisi perasan daun pepaya. Hasil penelitian ini berbeda dari hasil penelitian yang dilakukan oleh Ariest A.A., dkk. menunjukkan bahwa ada pengaruh larutan daun pepaya terhadap kematian larva. Adanya perbedaan hasil ini terletak pada sampel yang digunakan (penelitian ini menggunakan larva instar II) dan durasi pengamatan lebih lama (48 jam) (Ariesta A.A., 2014). Hasil yang berbeda pula ditunjukkan oleh Kurniawan, dkk. Penelitian tersebut menemukan bahwa ekstrak ethanol daun pepaya (Carica papaya L.) efektif sebagai larvasida terhadap larva Aedes aegypti instar III pada konsentrasi 1\%(Kristijanto, A.I., dkk., 2011).

Pada ketiga pengulangan penelitian, diketahui bahwa jumlah larva yang mati pada perasan daun cengkeh lebih banyak dibandingkan dengan jumlah larva yang mati pada perasan daun pepaya di tiap konsentrasi. Daun cengkeh dan daun pepaya, masing-masing mengandung senyawa yang dapat menyebabkan 
kematian pada larva. Tetapi pada penelitian ini, jumlah larva yang mati pada larutan yang mengandung perasan daun cengkeh dengan konsentrasi $10 \%$, 15\%, dan $20 \%$ jauh lebih banyak dibandingkan dengan larutan yang mengandung perasan daun pepaya.

Terdapat perbedaan jumlah larva yang mati di tiap 6 jam pada tiap pengulangan penelitian. Larva yang mati dapat dipengaruhi oleh beberapa faktor yang tidak dapat dikendalikan, di antaranya adalah suhu dan kadar keasaman air yang digunakan.

\section{KESIMPULAN DAN SARAN}

Rata-rata larva yang mati pada perasan daun cengkeh di tiap konsentrasi lebih banyak dibandingkan dengan perasan daun pepaya. Pada kontrol, tidak ada larva yang mati sama sekali. Bagi penelitian selanjutnya disarankan melakukan pengukuran terhadap variabel yang dapat mempengaruhi hasil penelitian, misalnya suhu. Membuat perbandingan kemampuan kedua daun tersebut dalam bentuk selain perasan, misalnya: perbandingan ekstrak daun cengkeh dan ekstrak daun pepaya.

\section{DAFTAR PUSTAKA}

Ariesta, A.A., dkk. Uji Efektifitas Larutan Daun Pepaya (Carica Papaya) Sebagai Larvasida terhadap Kematian Larva Nyamuk Ae Laboratorium B2P2VRP. Jurnal Fakultas Kesehatan Universitas Dian Nuswantoro.

Haditomo, Indriantoro. 2010. Efek Larvasida Ekstrak Daun Cengkeh (Syzygium aromaticum L.) terhadap Aedes aegypti L.. Skripsi Fakultas Kedokteran Universitas Sebelas Maret Surakarta Tahun 2010.

Hastutiningrum, N.O. Efek Minyak Atsiri Daun Cengkeh (Syzygium aromaticum L.) terhadap Mortalitas Larva Anopheles aconitus. Skripsi Fakultas Kedokteran Universitas Sebelas Maret Surakarta Tahun 2010.
Irwindiani, dkk. 2015. Uji Efektifitas Perasan Daun Pepaya sebagai Larvasida Terhadap Kematian Larva Anopheles sp. Bagian Kesehatan Lingkungan Fakultas Kesehatan Masyarakat Universitas Hasanuddin.

Kristijanto, A.I., dkk. Ekstrak Kasar Limbah Cengkeh (Syzigiumaromaticum L.) Fraksi Heksan Sebagai Larvasida Alami Terhadap Jentik Nyamuk Demam Berdarah (Aedes aegypti Linn) Instar III dan IV. Prosiding Seminar Nasional Sains dan Pendidikan Sains VII UKSW.

Kurniawan, B., Dkk. Effectiveness of The Pepaya Leaf (Carica Papaya Linn) Ethanol Extract as Larvacide For Aedes Aegypti Instar III. J Majority | Volume 4 Nomor 5|Februari 2015 176.

La Haeda, F. Gambaran Kondisi Kontainer Di Rumah Penderita Demam Berdarah Dengue (DBD) di Kota Ternate Tahun 2015. Karya Tulis Ilmiah Poltekkes Kemenkes Ternate Tahun 2015.

Nurdjannah, Nanan. Diversifikasi Penggunaan Cengkeh. Tahun 2004, Perspektif Volume 3 Nomor 2, Desember 2004 : 61 - 70 .

Sanjaya, dkk.. Efektivitas Daya Tolak Ekstrak Geranium Radula Cavan terhadap Nyamuk Aedes aegypti (Linn.). Tahun 2014: Jurnal Bionatura, Volume 16, Nomor 2, halaman $62-67$.

Shadana, M., dkk. 2014. Efek Larvasida Ekstrak Etanol Daun Pepaya (Carica Papaya) Terhadap Larva Aedes aegypti. Bagian Parasitologi Fakultas Kedokteran Universitas Riau.

Taher,dkk. 2015. Potensi Cengkeh (Syzygium aromaticum) Varietas Afo sebagai Larvasida Alami Nyamuk Anopheles subpictus dan Aedes aegypti. Tahun 2015: Jurnal Pros Sem Nas Masy Biodiv Indon Volume 1, Nomor 6. 